\title{
Depth Estimation of Reinforcing Steel Bars by using Pulsed-Magnetization
}

\author{
Michitaka Hori ${ }^{\mathrm{a}}$, Ryousuke Sana ${ }^{\mathrm{a}}$, Mochimitsu Komori ${ }^{\mathrm{a}, *}$
}

(Received July 5, 2015; revised September 24, 2015; accepted October 9, 2015)

\begin{abstract}
There are some non-destructive methods for estimating a depth of reinforcing steel bars in concrete structure. In this paper, we propose a technique for estimating the depths of reinforcing steel bars through the analysis using FEM and experiments. Reinforcing steel bars are magnetized by using pulse magnetization method. The spatial distribution of magnetic flux densities $B_{X}$, $B_{Y}, B_{Z}$ at the surface of concrete structures are measured. Two reinforcing steel bars are magnetized by using the pulse magnetic field in the same direction and the opposite direction. Magnetic flux densities $B_{Y}$ and $B_{Z}$ are measured for estimating the depth of reinforcing steel bars. We have confirmed that the depth of reinforcing steel bars is estimated by using our proposed method. Furthermore, FEM analysis is performed for the experiment. The depth of the reinforcing steel bars is found to be estimated by using FEM. Relationship between the real depth by using experiments and the estimated depth by using FEM are discussed in our paper.
\end{abstract}

キーワード : 鉄筋，パルス着磁，着磁器，磁束密度

Keywords : Reinforcing steel bar, Pulse magnetization, Magnetizer, Magnetic flux density.

\section{1.はじめに}

近年, 鉄筋コンクリート構造物の劣化は社会問題であ り, 劣化診断は重要となって来ている ${ }^{(1-3)}$ 。鉄筋の劣化 診断において, 鉄筋の位置, 鉄筋のかぶり厚（鉄筋まで のコンクリートの厚み）の検査は電磁放射レーダ法, 電 磁誘導法の技術を使用して行われる。電磁波レーダ法 ${ }^{(4-8)}$ は, コンクリートの誘電率を用いて鉄筋までの距離を 測定するため, 誘電率の変化を補正する必要があり, そ の補正方法について研究がなされている。電磁誘導法 ${ }^{(9,10)}$ は, 鉄筋間の距離が短いときの補正方法の研究がな されている。著者らは, 鉄筋をコンクリート表面からパ ルス着磁し，コンクリート表面における磁束密度の分布 を測定することにより鉄筋の位置，かぶり厚，鉄筋の直 径を推定する手法について研究を行なっている。先に, 単独（一本）配筋した状態での鉄筋の位置，かぶり厚，

\footnotetext{
* Corresponding author. E-mail: komori_mk@yahoo.co.jp

a 九州工業大学

干 804-8550 福岡県北九州市戸畑区仙水町 1-1

Kyushu Institute of Technology

1-1, Sensuicho Tobata-ku Kitakyushu-shi, Fukuoka, Japan $804-8550$
}

直径は，磁束密度分布を測定し，鉄筋位置において磁束 密度の方向が変わるところ, 最大の磁束密度を示す点な どの特徵点から推定する方式を提案した ${ }^{(11,12)}$ 。次に複数 配筋された鉄筋の位置を推定する方法を提案した。複数 配筋された鉄筋を最適回数のパルス着磁を行い，その磁 束密度分布から複数鉄筋の位置を推定する方式を実験に より検証した結果を報告した ${ }^{(14-16)}$ 。複数の鉄筋位置を推 定できることが明らかになったので，本論文では，複数 の鉄筋を二個のコイルを用いて同時に異極または同極で 着磁し, 複数配筋された鉄筋のかぶり厚を推定する方法 を提案し,コイル二個を用いて複数鉄筋を同時に着磁し， かぶり厚推定法の検証を行った。FEM解析と実験により 得られた磁束密度分布の比較を行い，鉄筋の磁化状態を 確認した。更に得られた磁束密度分布から本方式に基づ きかぶり厚推定し，かぶり厚を推定できることを確認し た。本論文においてパルス着磁を用いて複数鉄筋におけ るかぶり厚の推定法とその妥当性について報告する。参 考文献 ${ }^{(13)}$ は, コイル一個を用いて複数の鉄筋一本一本を パルス着磁し，かぶり厚を推定したものであり本論文と 手法が異なる。 


\section{2. 複数鉄筋におけるかぶり厚推定法}

\section{1 鉄筋の着磁方法}

コンクリート表面から鉄筋を着磁し，コンクリート表 面で磁束密度分布の測定を行うことから，鉄筋を十分に 着磁するためパルス着磁法を用いた。パルス着磁に使用 する着磁装置は, 磁界を発生するための着磁コイルと着 磁コイルにパルス状の電流を流すための着磁器により構 成される。着磁器のコンデンサ容量は $2000 \mu \mathrm{F}$ であり, 出力電圧 $50 \mathrm{~V} \sim 1.5 \mathrm{kV}$ の調整により発生磁界を可変する ことが可能である。着磁コイルは，内径 $30 \mathrm{~mm}$, 外径 $118 \mathrm{~mm}$, 高さ $86 \mathrm{~mm}$, 巻数 690 の空芯コイルを使用した。 鉄筋の着磁は，着磁コイルに数 $\mathrm{ms}$ のパルス電流を通電 して行った。本論文において，コイル中心の磁束密度は 数 $\mathrm{T}$ であり，水分に起因する誘電率は無視できコンクリ 一ト領域を空気領域と仮定した。パルス着磁法は, 装置 の小型化・低価格化を図ることができ, 機器に組み込ん で着磁が可能であるなど実用性があると考えている。

\section{2 コンクリート表面における磁束密度}

コンクリート表面において鉄筋の初期の残留磁化に 応じた磁束密度を測定する。鉄筋の残留磁化を取り除く ため必要に応じて着磁を行う前に消磁を行っている。磁 束密度は, 磁気感度 $5.0 \mathrm{~V} / \mathrm{mT}$, 感磁面 $1 \mathrm{~mm} \times 2 \mathrm{~mm}$ の磁気 センサを 3 方向測定できる様に構成し測定した。地磁気 や外部磁気の影響は，あらかじめ測定した磁束密度值を 減算することで除去している。磁束密度は仮想平面上に おいて Fig.1 に示した X, Y, $\mathrm{Z}$ 方向の座標を取る。鉄筋 長手方向を $\mathrm{X}$ 軸, 長手方向へ垂直な方向を $\mathrm{Y}$ 軸, 着磁二 イルの中心軸方向に相当し鉄筋に垂直な方向を $\mathrm{Z}$ 軸とす る。Z軸方向は, コンクリートのかぶり厚の方向である。

\section{3 鉄筋のかぶり厚推定法}

鉄筋のかぶり厚を推定する方法として，コンクリート 表面から $100 \mathrm{~mm}$ 離れた位置にある単独の鉄筋をパルス 着磁し，その磁束密度分布を測定し $\mathrm{Z}$ 軸方向の磁束密度 と Y 軸方向の磁束密度を用いてかぶり厚を推定する方法

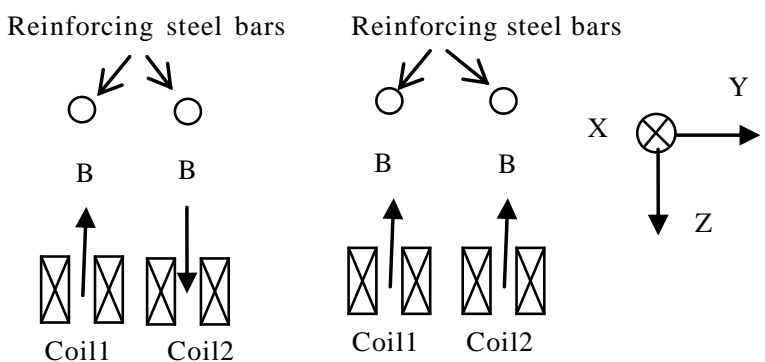

B:Direction of magnetic flux
(a) Different pole
(b) Same pole

Fig. 1. Experimental setup for magnetization method
を提案した ${ }^{(11,12)}$ 。実際にはコンクリート内部には複数配 筋されており，複数の鉄筋におけるかぶり厚推定方法に ついて詳述する。複数の鉄筋位置は，最適な着磁回数に より着磁を行い, 磁束密度分布を測定し, $\mathrm{Z}$ 軸方向の磁 束密度 $B_{Z}$ が鉄筋位置において最大值を示す特徴を用い て推定する方式を提案した ${ }^{(14)}$ 。その手法により鉄筋位置 を推定したのちに 2 本の鉄筋を同時に着磁する。各鉄筋 の直下にて Fig.1(a),(b)に示すように着磁コイルから発生 寸る磁界が逆方向（異極）の場合と同方向（同極）の場 合の着磁を行い, それぞれの磁束密度分布を鉄筋間の中 央点にて測定する。同極で着磁した場合及び，異極で着 磁した場合における着磁後の磁束密度のべクトル図を Fig.2 に示す。Z 軸方向の磁束密度 $B_{Z 1,2}, \mathrm{Y}$ 軸方向の磁束 密度 $B_{Y 1,2}$ とすると, 異極で着磁した場合, Fig.2(a)に示 すよう $\mathrm{Z}$ 軸方向の磁束密度 $B_{Z 1,2}, \mathrm{Y}$ 軸方向の磁束密度 $B_{Y 1,2}$ とすると, 異極で着磁した場合, Fig.2(a)に示すよう に $B_{Z 1}$ と $B_{Z 2}$ は打ち消し合い, $B_{Y 1}$ と $B_{Y 2}$ は合成され, 合 成された磁束密度を $B_{Y}$ とする。また，同極で着磁した

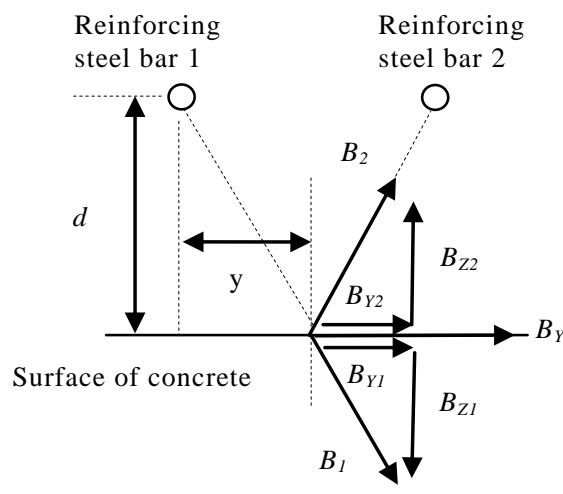

(a) Case of different pole-magnetization

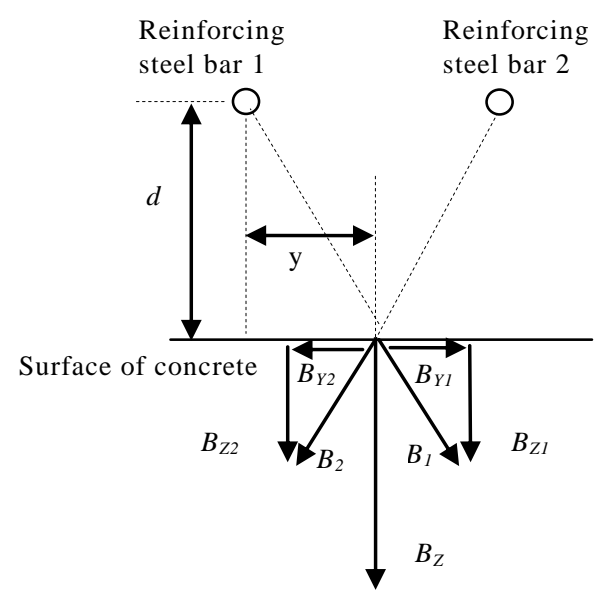

(b) Case of same pole- magnetization

Fig. 2. Magnetic flux density vector chart after magnetization 
場合，Fig.2(b)に示すように $B_{Y 1}$ と $B_{Y 2}$ は打ち消し合い, $B_{Z 1}$ と $B_{Z 2}$ は合成され, 合成された磁束密度を $B_{Z}$ とする。 コンクリート表面から鉄筋までのかぶり厚 $d$, 磁束密度 $B_{Z}, B_{Y}$ および鉄筋から鉄筋間の中央点までの距離 $y$ の関 係よりかぶり厚 $d$ は, 式(1)

$$
d=y \times B_{Z} / B_{Y}
$$

但し, $B_{Y}=B_{Y 1}+B_{Y 2} \quad, B_{Z}=B_{Z 1}+B_{Z 2}$

により推定することができる。

3. 磁束密度の解析とかぶり厚推定

\section{1 解析方法}

鉄筋のかぶり厚を推定するため, 2 本の鉄筋に対して 同極着磁と異極着磁を行う。鉄筋の同極着磁後と異極着 磁後にコンクリート表面における磁束密度を解析するた め, 汎用の FEM 解析ソフトを用いた。着磁コイルが発 生する磁界の強さを解析し，鉄筋の磁気特性は保磁力 7 $\mathrm{kA} / \mathrm{m}$, 着磁率, リコイル透磁率は実験から任意に設定し 静磁場により鉄筋を着磁し, 着磁後のコンクリート表面 に相当する位置での磁束密度分布の解析を行った。鉄筋 は長手方向に磁化され, 鉄筋の着磁点においてはラジア ル方向に磁束が発生する。鉄筋の磁化方向については参 考文献 ${ }^{(11,14)}$ において実験・解析を通して確認した。鉄筋 から 100mm 離れた位置にある 2 個の着磁コイルに 450A を通電して解析を行った。2 本の鉄筋は長さ $1 \mathrm{~m}$, 直径 $25 \mathrm{~mm}$ ，鉄筋間隔を $150 \mathrm{~mm} ， 200 \mathrm{~mm} ， 250 \mathrm{~mm}$ とした。鉄 筋は, Fig.2 に示すように X 軸方向を鉄筋の長手方向と し，鉄筋間の中央点を $\mathrm{Y}$ 軸原点として 2 本配置した。 $\mathrm{X}$ 軸原点は着磁点である。鉄筋間隔が $150 \mathrm{~mm}$ の時は, Y 軸 $-75 \mathrm{~mm}$ と $75 \mathrm{~mm}$ に鉄筋 2 本を配置した。解析領域は, 鉄 筋を中央部に配置し, $\mathrm{X}$ 軸方向 $3 \mathrm{~m}, \mathrm{Y}$ 軸方向 $2 \mathrm{~m}, \mathrm{Z}$ 軸 方向 $2 \mathrm{~m}$ の空間であり, 磁束密度分布は $\mathrm{X}$ 軸, $\mathrm{Y}$ 軸とも $\pm 200 \mathrm{~mm}$ の範囲を求めた。

3.2 解析によるかぶり厚の推定結果

鉄筋間隔 $150 \mathrm{~mm}$ におけるコンクリート表面での磁束 密度分布をFig.3, Fig4 に示す。Fig.3(a),(b)は異極着磁に おける磁束密度 $B_{Y}, B_{Z}$ をそれぞれ示し，Fig.4(a),(b)は同 極着磁における磁束密度 $B_{Y}, B_{Z}$ それぞれを示す。横軸は $\mathrm{X}$ 軸方向, 縦軸は $\mathrm{Y}$ 軸方向を示し $400 \mathrm{~mm} \times 400 \mathrm{~mm}$ の平面 における磁束密度分布を示す。異極で着磁した場合,

Fig.2(a)で示したように磁束密度 $B_{Y}$ は, 2 本の鉄筋の磁束 密度が合成され大きくなることが分かる。磁束密度 $B_{Z}$ は，逆に鉄筋の磁束密度が打ち消し合いゼロとなること が分かる。同極で着磁した場合，Fig.2(b)で示したように 磁束密度 $B_{Y}$ は, 2 本の鉄筋の磁束密度が打ち消し合いゼ ロとなることが分かる。磁束密度 $B_{Z}$ は, 逆に 2 本の鉄筋 の磁束密度が合成され大きくなることが分かる。

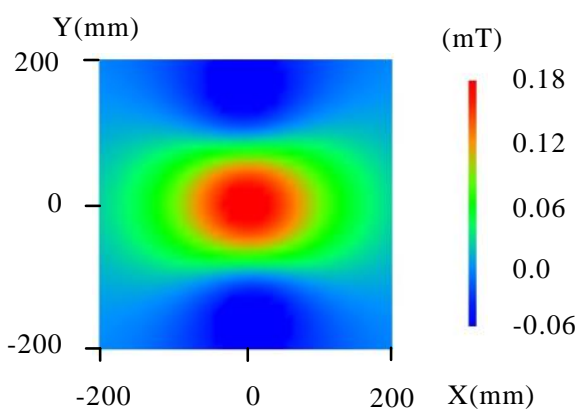

(a) Distribution of magnetic flux density $B_{Y}$

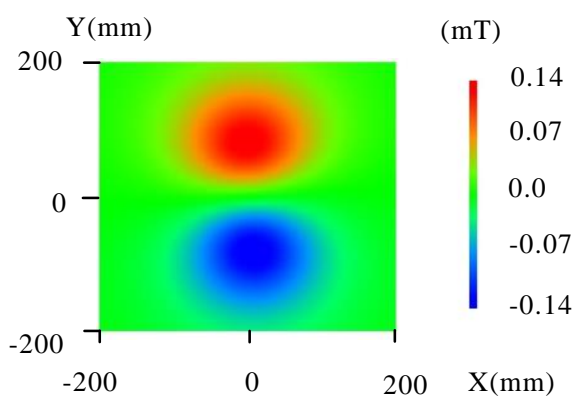

(b) Distribution of magnetic flux density $B_{Z}$

Fig. 3. Analysis results of distribution of magnetic flux density in the case of different pole-magnetization

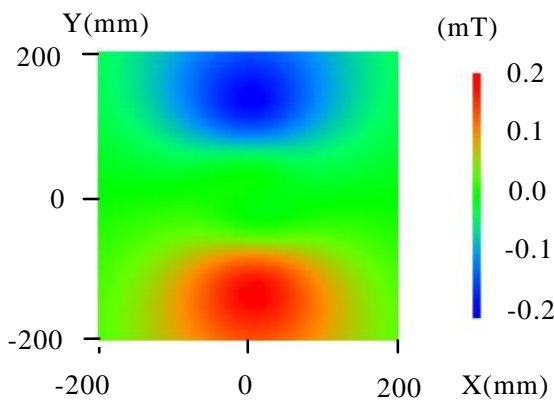

(a) Distribution of magnetic flux density $B_{Y}$

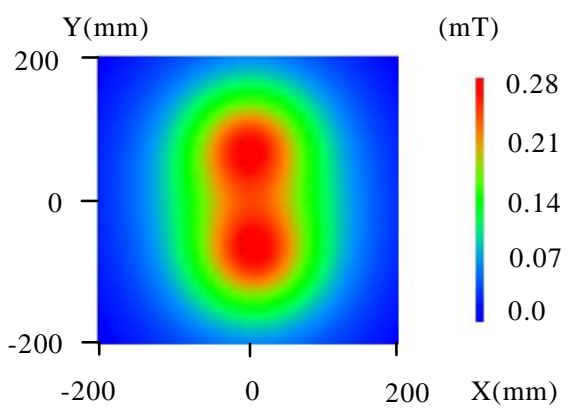

(b) Distribution of magnetic flux density $B_{Z}$

Fig. 4. Analysis results of distribution of magnetic flux density in the case of same pole-magnetization 
鉄筋間隔 $150 \mathrm{~mm} ， 200 \mathrm{~mm} ， 250 \mathrm{~mm}$ において鉄筋中心に おける Y 軸方向-200mm〜200mm までの磁束密度分布を Fig.5 に示す。Fig.5(a)は異極着磁後における磁束密度分 布 $B_{Y}$ を示し, Fig.5(b)は同極着磁後における磁束密度分 布 $B_{Z}$ を示す。鉄筋間の中央点における磁束密度 $\left(B_{Y}, B_{Z}\right)$ は，鉄筋 $150 \mathrm{~mm}$ 時に $(0.179 \mathrm{mT}, 0.239 \mathrm{mT}), 200 \mathrm{~mm}$ 時に $(0.166 \mathrm{mT}, 0.166 \mathrm{mT}), 250 \mathrm{~mm}$ 時に $(0.141 \mathrm{mT}, 0.113 \mathrm{mT})$ で あり, これらの磁束密度と鉄筋から測定位置までの距離 $y$ を用いて式(1)に基づき，かぶり厚 $d$ の推定を行った。 測定は，2 本の鉄筋間の中央点で行っており，鉄筋から 測定位置までの距離 $y$ は，鉄筋間隔 $150 \mathrm{~mm}, 200 \mathrm{~mm}$, $250 \mathrm{~mm}$ に対してそれぞれ $75 \mathrm{~mm}, 100 \mathrm{~mm}, 125 \mathrm{~mm}$ である。 推定したかぶり厚と鉄筋間隔の関係を Fig.6 に示す。鉄 筋間隔 $150 \mathrm{~mm}, 200 \mathrm{~mm}, 250 \mathrm{~mm}$ においてかぶり厚 $100 \mathrm{~mm}$ を精度良く推定することが可能であることが分かる。こ の結果，鉄筋直下において異極と同極で着磁し，その磁 束密度 $B_{Y}, B_{Z}$ の測定結果と鉄筋から測定点までの距離 $y$ を用いて式(1)により鉄筋のかぶり厚を推定できること を確認した。

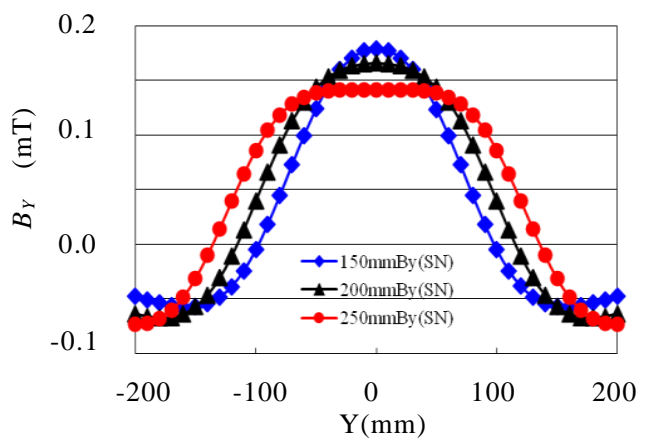

(a) Distribution of magnetic flux density $B_{Y}$ in the case of different pole-magnetization

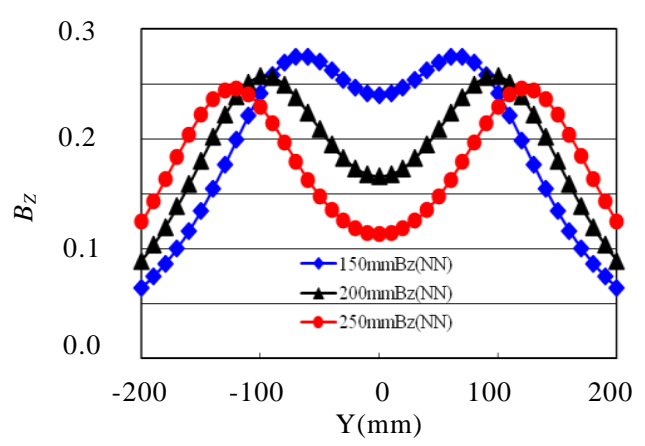

(b) Distribution of magnetic flux density $B_{Z}$ in the case of same pole-magnetization

Fig. 5. Analysis results of distribution of magnetic flux density $B_{Y}$ and $B_{Z}$

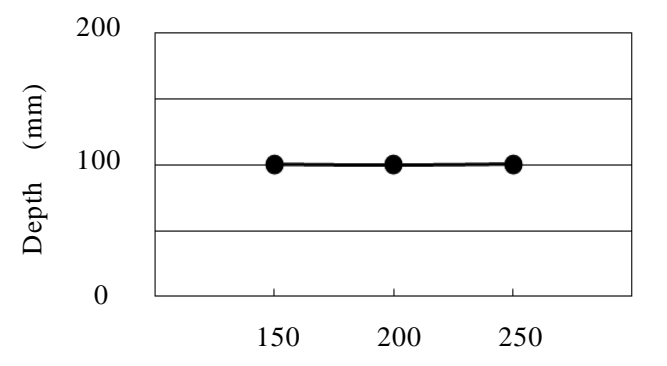

Distance of two reinforcing steel bars (mm)

Fig. 6. Estimated result of depth of reinforcing steel bars by analysis

\section{4. かぶり厚推定実験}

\section{1 実験方法}

次に，実際に鉄筋を着磁し磁束密度分布からかぶり厚 を推定する実験を行った。実験に用いた鉄筇は，直径 $25 \mathrm{~mm}$ の異形鉄筋 2 本を用い, かぶり厚 $100 \mathrm{~mm}$ を想定し, コンクリートは空気と仮定して実験を行った。鉄筋間隔 は，解析を行った $150 \mathrm{~mm}, 200 \mathrm{~mm}, 250 \mathrm{~mm}$ とした。着 磁条件は，着磁電圧 $1500 \mathrm{~V}$, コンデンサ容量 $2000 \mu \mathrm{F}$ に より着磁した。着磁はコイル 2 個を使用して行った。 2 本の鉄筋は, かぶり厚 $100 \mathrm{~mm}$ に相当する位置に, 各鉄 筋間隔に非磁性材であるべーク板の上に設置した。異極 着磁の場合，鉄筋 2 本の直下にコイルを配置し，コイル の発生磁場が異極となるようにパルス電流を通電して着 磁を行った。また同極着磁の場合，鉄筋 2 本の直下にコ イルを配置し，コイルの発生磁場が同極となるようにパ ルス電流を通電して着磁を行った。これらの 2 本の鉄筋 は，非磁性材であるベーク板の上に設置してあり，コン クリート表面に相当する $100 \mathrm{~mm}$ 離れた位置において磁 気センサを走査して磁束密度を測定し，かぶり厚推定を 行った。

\section{2 実験結果}

解析により得られた磁束密度分布と比較するため実 験で得られた鉄筋間隔 $150 \mathrm{~mm}$ におけるコンクリート表 面に相当する位置での磁束密度分布を Fig.7，Fig.8 に示 す。Fig.7(a),(b)は異極着磁における磁束密度 $B_{Y}, B_{Z}$ をそ れぞれ示す。解析結果と同様に磁束密度 $B_{Y}$ は， 2 本の鉄 筋の磁束密度が合成され大きくなり, 磁束密度 $B_{Z}$ は, 逆 に鉄筋の磁束密度が打ち消し合いほぼゼロとなっている。 Fig.8(a),(b)は同極着磁における磁束密度 $B_{Y}, B_{Z}$ をそれぞ れ示す。解析結果と同様に磁束密度 $B_{Y}$ は，2 本の鉄筋の 磁束密度が打ち消し合いほぼゼロであり, 磁束密度 $B_{Z}$ は, 逆に 2 本の鉄筋の磁束密度が合成され大きくなって いる。実験結果は, 解析結果と同様の分布傾向を示して いることを確認した。解析結果と実験結果に若干の差が あるが，測定誤差によるものと考えている。鉄筋間隔 


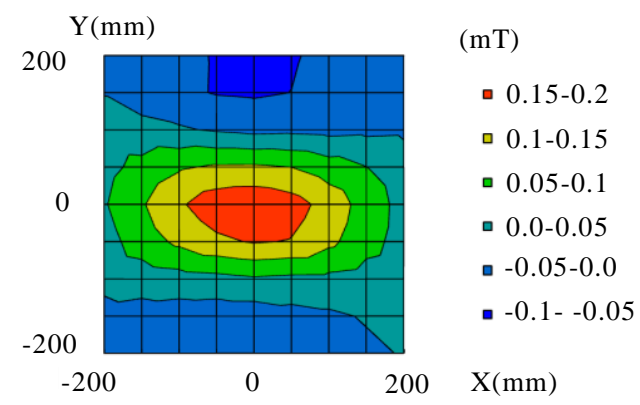

(a) Distribution of magnetic flux density $B_{Y}$

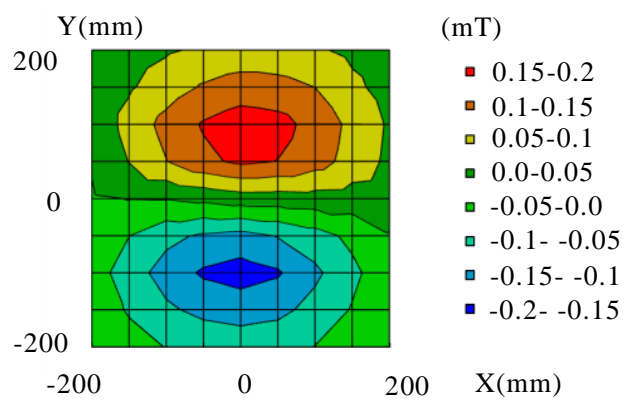

(b) Distribution of magnetic flux density $B_{Z}$

Fig. 7. Experimental results of distribution of magnetic flux density in the case of different pole-magnetization

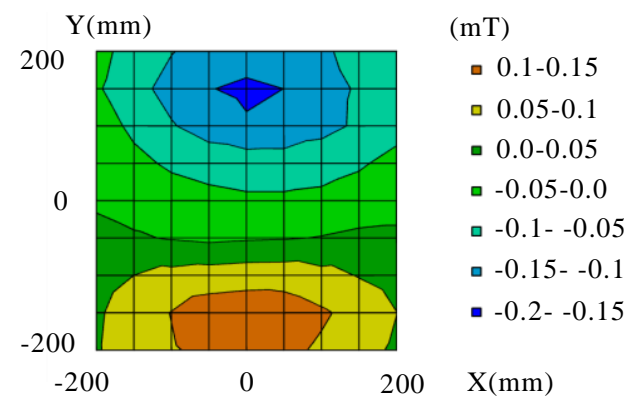

(a) Distribution of magnetic flux density $B_{Y}$

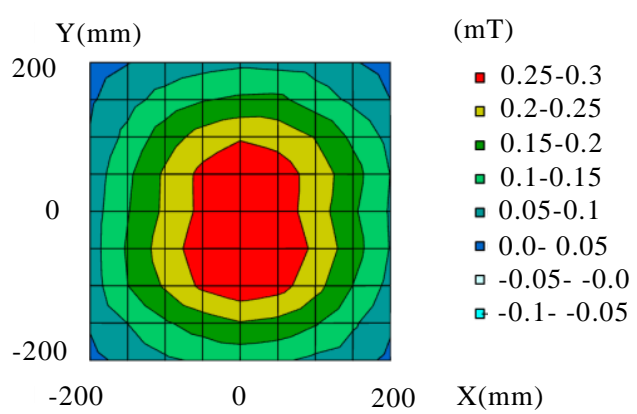

(b) Distribution of magnetic flux density $B_{Z}$

Fig. 8. Experimental results of distribution of magnetic flux density in the case of same pole-magnetization
$150 \mathrm{~mm}, 200 \mathrm{~mm} ， 250 \mathrm{~mm}$ における鉄筋中央部での実験で 得られた磁束密度分布を示す。Fig.9(a)は，鉄筋を 2 本同 時に異極となるように着磁した場合の磁束密度分布 $B_{Y}$ を示す。解析結果と比較すると $150 \mathrm{~mm}$ と $200 \mathrm{~mm}$ のピー ク值の差異が小さいようであるが，実験結果は解析結果 と同様の傾向を示している。Fig.9(b)は，鉄筋を 2 本同時 に同極となるように着磁した場合の磁束密度分布 $B_{Z}$ を 示す。解析結果と比較すると, それぞれの鉄筋間隔での 実験による磁束密度分布は, 解析結果を再現している。 また，鉄筋位置付近でピーク值を示し，2 本の鉄筋のピ ーク值はほぼ一致している。実験により測定した異極着 磁による磁束密度 $B_{Y}$ と同極着磁による磁束密度 $B_{Z}$, 及 び鉄筋から測定位置までの距離 $\mathrm{y}$ を用いて式(1)に基づ きかぶり厚 $d$ の推定を行った。その結果，かぶり厚と鉄 筋間隔の関係を Fig.10 に示す。かぶり厚推定值は，鉄筋 間隔 $150 \mathrm{~mm}, 200 \mathrm{~mm} ， 250 \mathrm{~mm}$ において，真值 $100 \mathrm{~mm}$ に 対して各々 $101 \mathrm{~mm}, 106 \mathrm{~mm}, 116 \mathrm{~mm}$ であり，鉄筋間隔が 長くなるにつれてかぶり厚が大きく推定される結果とな つた。誤差率は, 各々 $1 \%, 6 \%, 16 \%$ あった。かぶり厚 推定による真值との誤差の要因は，鉄筋間隔が長くなる

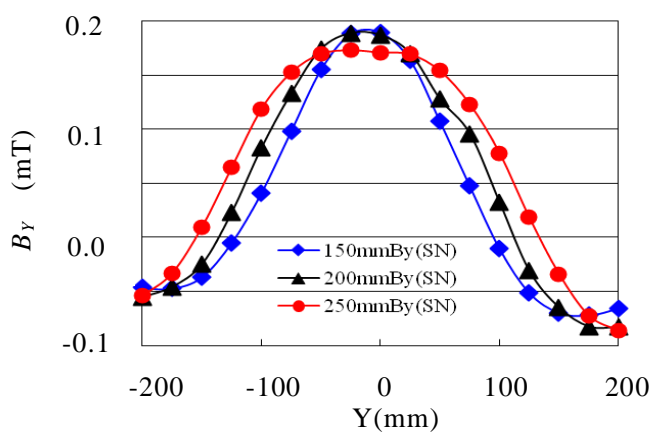

(a) Distribution of magnetic flux density $B_{Y}$ in the case of different pole-magnetization

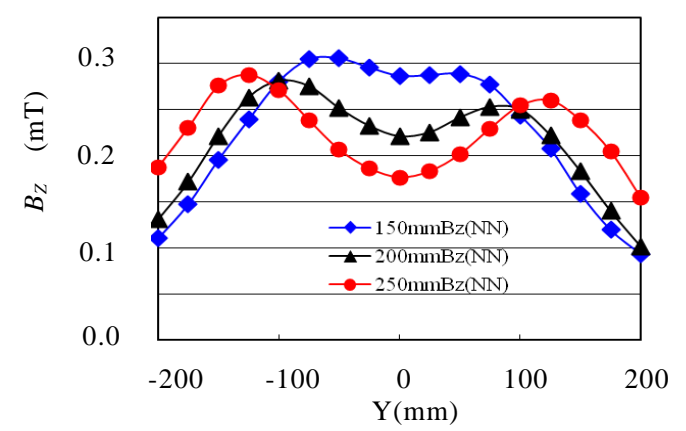

(b) Distribution of magnetic flux density $B_{Z}$ in the case of same pole-magnetization

Fig. 9. Experimental results of distribution of magnetic flux density $B_{Y}$ and $B_{Z}$ 


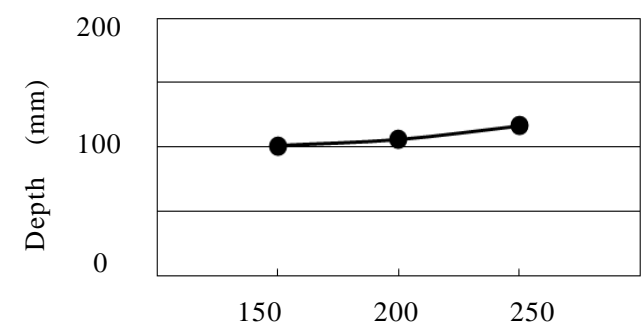

Distance of two reinforcing steel bars (mm)

Fig. 10. Estimated result of depth of reinforcing steel bars by experiment

に従い磁束密度が微小となるため, 磁気センサの方向・ 位置合わせによる誤差によるものと推測している。今後, 測定プローブの方向・位置については, 機械的に精度良 く制御した測定方法に改善して行く予定である。測定誤 差は，実用上問題にならない範囲であると考えている。 今回の検証により，本手法は複数配筋された鉄筋のかぶ り厚を推定できることを確認した。

\section{5.おおりに}

鉄筋コンクリート構造物において劣化診断を行う上 で，鉄筋のかぶり厚を推定することは重要である。著者 らは, パルス磁界を用いて鉄筋の位置を推定する手法を 提案し，本論文において鉄筋の位置を推定した後にパル ス着磁を用いてかぶり厚を推定する方法を提案した。位 置が既知である 2 本の鉄筋の直下に 2 個のコイルを配置 し, 異極で着磁し磁束密度 $B_{Y}$ を測定する。更に同極で着 磁し磁束密度 $B_{Z}$ を測定する。測定した磁束密度 $B_{Y}, B_{Z}$ 用い，本方式により鉄筋のかぶり厚を推定できることを FEM 解析および実験により確認した。今後, 効率良くか ぶり厚を推定できる様に改良を加えるとともに，メッシ ユ構造の配筋状態におけるかぶり厚の推定，さらに測定 精度向上について基礎研究を行っていくとともに，本手 法は, 新規な測定法であり電磁誘導法, 電磁波レーダ法 など従来法との優位性についても研究により明らかにし て行く予定である。

\section{文献}

(1) 笠井芳夫:「コンクリート構造物への非破壊検査の展開 コンクリ 一トの非破壊試験・検査の進展状況」, 非破壊検査, Vol. 56, No. 2, pp. $77-83,2007$

(2) 魚本健人, 加藤潔, 広野進:「コンクリート構造物の非破壊検査」, 森北出版株式会社, pp. 6-20, 2000

(3) T.Uomoto : "Non-Destructive Testing in Civil Engineering 2000", Published By Elesevier, pp. 615-678, 2000
（4）森濱和正：「非破壊・微破壊試験によるコンクリート構造物の品質 検查(1) 共同研究の内容と成果の概要」, 非破壊検査, Vol. 58, No. 4, pp. $126-131,2009$

（5）田中正吾, 岡本昌幸:「電磁波レーダを用いた鉄筋の腐蝕厚計測（第 二報)」, 日本非破壊検査協会, 平成 21 年度春季大会講演概要集, pp. 157-160, 2009

(6) Hubbard S.S., J.Zhang, P.J.Monteiro, J.E.Petrson, and Y.Rubin : "Experimental Detection of Reinforcing Bar Corrosion Using Nondestructive Geophysical Techniques”, ACI Materials Journal, Vol. 100, No. 6, pp. 501-509, 2003

(7) Shaw M.R., S.G.Millard, and T.C.K.Molyneaux : "Location of Steel Reinforcement in Concrete using ground penetrating Radar and Neural Networks", NDT\&E International, Vol. 38, No. 3, pp. 203-212, 2005

(8) S. Tanaka, and M.Wakabayashi : "On Measurement of the Depth and the Diameter of Steel Bars in Reinforced Concrete Using Electromagnetic Wave (Radar)", SICE-ICASE International Joint Conference, No. 18-21, pp. 2555-2559, 2006

（9）飯田洋志，松本功，久富真悟，森濱和正：「非破壊・微破壊試験に よるコンクリート構造物の品質検査(2)非破壊試験によるコンク リート構造物の鉄筋かぶり厚さの測定」, 非破壊検査, Vol. 58, No 4, pp. 132-137, 2009

(10) Benitez D.S., Sung Quek, Gaydecki, and P.Torres V. : "A 1-D Solid-State-Sensor-Based Array System for Magnetic Field Imaging of Steel Reinforcing Bars Embedded within Reinforced Concrete", IEEE Transaction on Instrumentation and Measurement, Vol. 58, No. 9, pp 3335-3340, 2009

（11）小森望充，堀充孝，深川卓哉：「パルス着磁を用いた鉄筋のかぶり と直径の新しい評価方法」, 日本 AEM 学会誌, Vol. 19, No. 1, pp. $63-67,2011$

(12) M.Hori, R.Sana, and M.Komori : "Proposal of Non-Destructive Evaluation Method for Reinforcing Steel Bars by Using Pulsed-Magnetization”, International Conference Electrical Engineering (Hong Kong, July, 2011), pp. 1-6, 2011

(13) M.Hori, R.Sana, and M.Komori : "Depth Estimation of Reinforcing Steel Bars by Using Pulsed-Magnetization”, International Conference Electrical Engineering (Hong Kong, July, 2011), pp. 1-6, 2011

(14) 堀充孝, 眞亮介, 小森望充:「パルス着磁による鉄筋位置の推定法」, 日本 AEM 学会誌, Vol. 21, No. 2, pp. 176-181, 2013

(15) M.Hori, R.Sana, and M.Komori : "Estimation Method of the Positions of Reinforcing Steel Bars by Using Pulsed-Magnetization”, International Conference Electrical Engineering (Xiamen, July, 2013), pp. 1-6, 2013

(16) M.Hori, R.Sana, and M.Komori : "Estimation Method of the Positions of Reinforcing Steel Bars by Using Pulsed-Magnetization", Journal of International Council on Electrical Engineering, Vol. 4, pp. 315-318, 2014 

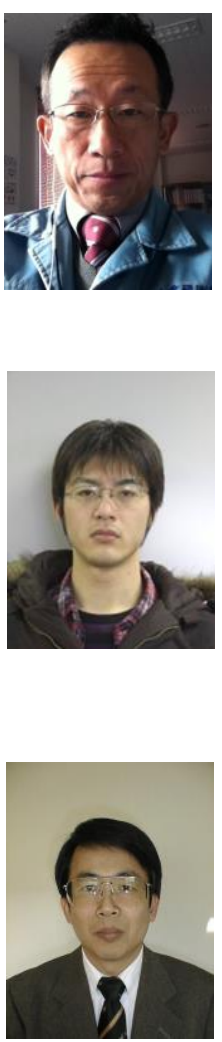

堀 充孝

1986 年 3 月明治大学工学部電気工学専攻修了。 2009 年 4 月九州工業大学大学院工学研究院先端機 能システム工学系研究院博士課程入学, 現在に至 る。鉄筋コンクリート構造物における非破壊検査 の研究に従事。

\section{眞亮介}

2009 年 3 月九州工業大学先端機能システム工学 学科卒業。2011 年 4 月九州工業大学大学院工学研 究院先端システム工学修了。鉄筋コンクリート構 造物における非破壊検查の研究に従事。

小森 望充

1984 年 3 月大阪大学基礎工学研究科制御 工学分野修了。2008 年 4 月九州工業大学大 学院工学研究院先端機能システム工学研究 系教授, 現在に至る。磁気浮上及び超電導応 用メカトロニクスの研究に従事。 